DARIUSZ JAROSZ

Instytut Historii im. Tadeusza Manteuffla PAN

\title{
PROBLEM ZANIECZYSZCZEŃ WÓD W POLSCE W LATACH 1945-1961: WSTĘP DO BADAŃ
}

Zarys treści: Artykuł zawiera jedną z pierwszych prób historycznej analizy opartej na badaniach źródłowych zanieczyszczenia wód w Polsce w latach 1945-1961, tj. od końca II wojny światowej do uchwalenia ustawy o ochronie wód przed zanieczyszczeniami. Autor próbuje odpowiedzieć na pytania o najważniejsze elementy składowe oraz uczestników dyskursu na temat czystości wód w Polsce oraz kreśli obraz zanieczyszczeń wód i problemów z tym zwiąanych, jaki wyłania się z analizowanych dokumentów. Podstawę źródłową opracowania, oprócz specjalistycznej prasy naukowej i popularnonaukowej, stanowią wcześniej niewykorzystywane przez historyków materiały przechowywane w Archiwum Akt Nowych, w takich zespołach, jak: Państwowa Komisja Planowania Gospodarczego, Ministerstwo Zeglugi i Gospodarki Wodnej, Kancelaria Sejmu PRL, Ministerstwo Gospodarki Komunalnej, oraz korespondencja wpływająca do Biura Listów Polskiego Radia, aktualnie dostępna w Archiwum Dokumentacji i Zbiorów Programowych TVP S.A. Opracowanie stara się również ustalić, kiedy pojawia się świadomość ekologiczna społeczeństwa polskiego oraz jakie postawy i zachowania można uznać za symptomy jej narodzin.

The content outline: The paper contains one of the first attempts to carry out a historical analysis of water pollution in Poland in the years 1945-1961, i.e. from the end of World War II until the adoption of the Act on the protection of waters against pollution, on the basis of available source studies. The author aims to answer the question concerning the most important components and participants of the discourse on the quality of Polish waters and provides a description of water pollution and its consequences based on the analysed source materials. Apart from specialised academic and popular science press, the main basis for the overview are materials which have not yet been exploited by historians. They are kept in the Archive of New Records in such fonds as: Państwowa Komisja Planowania Gospodarczego [National Commission for Economic Planning], Ministerstwo Żeglugi i Gospodarki Wodnej [Ministry of Navigation and Water Management], Kancelaria Sejmu PRL [Chancellery of the Sejm of the People's Republic of Poland], Ministerstwo 
Gospodarki Komunalnej [Ministry of Public Utilities], and incoming correspondence of the Letter Office of the Polish Radio, currently available at the Archive of Documentation and Programme Collection of TVP S.A. The paper is also aimed at determining the time of the appearance of environmental conscience among the Polish population, as well as the attitudes and behaviours that can be seen as the symptoms of its emergence.

Słowa kluczowe: ekologia, zanieczyszczenie wód, komunizm a ochrona środowiska, środowisko naturalne w PRL

Keywords: ecology, water pollution, communism and environmental protection, natural environment in the People's Republic of Poland

W dotychczasowych badaniach dziejów Polski po II wonie światowej problemy degradacji środowiska naturalnego sa „biała plamą”. Brak jest monografii tego tematu, dyskurs naukowy jest prowadzony przez specjalistów innych dziedzin wiedzy; od lat 60. publikowane sa specjalistyczne prace, będące efektem analiz zanieczyszczen, jak tė̇ ujęcia dotyczące specyficznych aspektów ochrony środowiska (prawnych, ekonomicznych, społecznych) ${ }^{1}$.

Zanim ta tematyka stanie się przedmiotem wyczerpujących studiów historyków polskich warto zacząć od badań cząstkowych, dotyczących najważniejszych części składowych środowiska naturalnego. Jednym $\mathrm{z}$ nich sa bez watpienia zasoby wodne.

W przedstawianym szkicu została podjęta próba odpowiedzi na dwa podstawowe pytania: 1) Jakie były najważniejsze elementy składowe oraz uczestnicy dyskursu² na temat czystości wód w Polsce? 2) Jaki obraz zanieczyszczeń wód i problemów z tym związanych wyłania się z dostępnych źródeł?

${ }^{1}$ Zob. m.in.: Ekonomiczne $i$ socjologiczne problemy ochrony środowiska, red. A. Ginsbert-Gebert, Wrocław-Warszawa-Kraków 1985; Ekonomiczne i socjologiczne problemy ochrony środowiska, red. A. Ginsbert-Gebert, t. 2, Wrocław-WarszawaKraków 1988; W. Brzeziński, Ochrona prawna biologicznego środowiska człowieka, Warszawa 1971; J. Aleksandrowicz, Wptyw zmian środowiska na zdrowie człowieka, Wrocław 1975; J. Jakubowski, Motoryzacja i ochrona środowiska, Warszawa 1976; J. Juda, Ochrona powietrza atmosferycznego, Warszawa 1974; Ekonomiczne aspekty ochrony środowiska, red. A. Ginsberg-Gebert, Warszawa 1976; L. Łustacz, Podstawowe zagadnienia prawne i organizacyjne ochrony środowiska, Warszawa 1976; System ochrony środowiska $w$ Polsce, Wrocław 1978; A. Symonowicz, Bilans strat powstatych wskutek degradacji środowiska, Warszawa 1990.

${ }^{2}$ Pojęcie dyskurs jest rozumiane przeze mnie jako określenie zbioru istniejących w sferze publicznej wypowiedzi według zadanego kryterium tematycznego. 
O ile początkowa cezura tych rozważań wydaje się oczywista, to wyjaśnienia wymaga cezura końcowa. W 1961 r. uchwalona została ustawa o ochronie wód przed zanieczyszczeniami. Kończy ona pewien etap polityki państwa w tym zakresie. Wybór tego okresu wynikał również z faktu, iż opracowania specjalistyczne na ten temat najczęściej zajmuja się czasami późniejszymi, łatwiejszymi do analizy ze względu na bogactwo badań, opracowań statystycznych, monografii szczegółowych. Uznałem, że warto wiedzieć, jak było wcześniej, poszukać genealogii zjawisk opisanych w literaturze przedmiotu.

\section{Lata 1945-1953}

W przekazach propagandowych z okresu tuż powojennego i apogeum stalinizmu motyw rzek i jezior pojawia się rzadko, a jeżeli już to w tonacji radosnej. Wizja czystych rzek i jezior towarzyszyła co roku obrazom szczęśliwych dzieci i młodzieży, przebywających na koloniach i obozach letnich oraz dorosłych wypoczywających w ośrodkach wczasów pracowniczych. Woda w kranie to również fragment radosnej wizji nowego, wyposażonego we wszystkie instalacje budownictwa mieszkaniowego. Problem zanieczyszczenia wód jako temat odrębny w ówczesnym dyskursie publicystycznym pojawiał się nie tylko rzadko, ale również w sposób ograniczony przede wszystkim do periodyków specjalistycznych. Dodatkowo, w okresie apogeum stalinizmu, był on mocno spętany w pewien symptomatyczny dla klimatu politycznego tego czasu sposób.

W latach 1945-1948 w periodykach przeznaczonych dla waskiego kręgu odbiorców można odnaleźć nuty krytyki zaniedbań w tym zakresie i ich dalekosiężnych skutków. Bronisław Rudziński w specjalistycznym czasopiśmie „Gaz, Woda i Technika Sanitarna” pisał w 1946 r.: „Nasze zaopatrzenie wodne było złe [przed wojna] i jest obecnie jeszcze gorsze. Na wodzie mętnej, twardej, żelazistej lub zakażonej, źle i w niedostatecznej ilości rozprowadzanej, cierpi nie tylko organizm ludzki, ale również gospodarstwa miejskie i wiejskie, przemysł przetwórczy i gospodarka cieplna, pomijając już tę okoliczność, że stacje wodociagowe sa źródłem dochodów dla samorządów i pociagają za sobą rozbudowę kanalizacji i oczyszczalni ścieków, a więc przyczyniają się do podnoszenia stanu sanitarnego i do kulturalnego wyglądu miast i osiedli”. Palącym zagadnieniem i obowiązkiem jest dostarczenie naszej ludności wody z „dotychczasowych rozporządzalnych źródeł, ale doszczętnie pozbawionej bakterii chorobotwórczych, jaj pasożytów i bakterii pochodzenia kałowego. Stan fizyczny naszego społeczeństwa jest silnie 
osłabiony wskutek długoletnich wstrzasów wojennych i złego odżywiania, a warunki higieniczne, w jakich żyjemy w miastach i osiedlach, dotkniętych działaniami wojennymi lub perfidna siła niszczycielska wroga, sa tego rodzaju, że używana przez nas codziennie woda, nawet z lekka zakażona, wywołuje pośrednio lub bezpośrednio swe zgubne następstwa w przyspieszonym tempie i w skali wyższej, aniżeli bywało dawniej. Mówiąc o pośrednim wpływie wody na zdrowie ludzkie, mam na myśli przede wszystkim fakt zaopatrywania naszych miast w mleko rozrzedzone woda, której zarazki znajduja w mleku dobra pożywkę i szybko się rozmnażają tak, że mleko staje się źródłem groźnej infekcji, a zwłaszcza dla niemowląt, pomijając, że prawie $40 \%$ mleka pochodzi od krów gruźliczych”3.

Jeszcze w 1949 r. w cytowanym periodyku można odnaleźć wzmianki o budzącej coraz większy niepokój skali zanieczyszczenia rzek: „Puste i smutne sa brzegi Odry. Rzeka jest z dala prawie niewidoczna; wryła się głęboko w ziemię ślasską i płynie ponuro w wiekowym zaniedbaniu, nie doczekawszy się dotąd ochrony należnej wodom publicznym". Autorzy cytowanego opracowania pisali ponadto, że Odra jest silnie zanieczyszczona ściekami przemysłowymi już „na terenie czechosłowackim”. Troska o należytą ochronę wód odrzańskich - twierdzili - winna spaść przede wszystkim na naszych sasiadów, którzy przez wydanie odpowiednich zarządzeń i dopilnowanie ich, wpłynęliby na polepszenie jakości wód. „Dopływy Odry na terenie górnoślasskim wpływają bezsprzecznie na zanieczyszczenie wód odrzańskich, nie są jednak wyłącznym źródłem zanieczyszczania wód, a jedynie podtrzymuja pierwotne zanieczyszczenie Odry z terenów czechosłowackich tak, że jakość wód Odry ani się nie polepsza, ani też pogarsza na trasie Olza-Skorogoszcz. W każdym razie Śląsk nie jest, jak dotąd ogólnie przypuszczano, tym wyłącznym sprawcą stałego zanieczyszczania wód odrzańskich”. Przemysł śląski nie może jednak wychodzić z założenia, że może spuszczać do Odry i własne zanieczyszczenia ściekowe ${ }^{4}$.

Jednak około 1949 r. ów sposób pisania o zanieczyszczaniu wód zaczyna się zmieniać. Akcent został położony na historyczne zaniedbania i ich skutki w okresie międzywojennym. Jan Wierzbicki przypominał takie wydarzenia, jak: zatrucie Zalewu Wiślanego w 1923 r., masowe śnięcia ryb w 1930 r. z powodu odprowadzenia ścieków z papierni

${ }^{3}$ B. Rudziński, Zagadnienie dobrej wód jako warunek dobrego zdrowia, „Gaz, Woda i Technika Sanitarna" 1946, nr 1, s. 20-21.

${ }^{4}$ W. Mroziński, E. Niedzielowa, A. Sobota, Odra i jej doptywy na odcinku górnoślaskim, „Gaz, Woda i Technika Sanitarna” 1949, nr 11, s. 361-363. 
Malta pod Poznaniem do rzeki Cybiny oraz zimą 1927/1928 i 1928/1929 zanieczyszczenie wód Obry. W konkluzji tych rozważań pisał: „Jeżeli dążenie do niezanieczyszczania naszych rzek i jezior będzie powszechne i obejmie nie tylko czynniki bezpośrednio poszkodowane: ludność nadbrzeżnych osiedli, rolników, rybaków oraz przemysł (zainteresowany w czystej wodzie rzecznej), lecz całe społeczeństwo, to żywić można nadzieję, że groźne skutki zanieczyszczenia naszych wód publicznych należeć będą do przeszłości”"

Ton oskarżeń kapitalistycznej przeszłości zaprezentował w 1952 r. Adolf Joszt, profesor Politechniki Ślaskiej. Pisał, iż przymus oczyszczania ścieków „stosowany dla ochrony rzek wygląda [...] zupełnie odmiennie w różnych ustrojach społecznych, w krajach kapitalistycznych rządzi tu tylko gra interesów, a wszakże kosztowne to oczyszczanie ścieków nie jest wcale «dobrym interesem» - szczególnie, jeśli miałby to być «interes» kapitału obcego i wrogiego danemu krajowi. Tymczasem w ustroju sprawiedliwości społecznej, w ustroju socjalistycznym, ośrodkiem troski ustawodawczej jest sam człowiek. Wobec tego, dopiero w takim ustroju sprawa ochrony rzek staje się rzeczą istotna i nieodzownie konieczna, gdyż ma na celu wspólne dobro każdego obywatela. Dzisiejszy fatalny stan czystości naszych rzek - szczególnie na śląskim terenie - jest właśnie spowodowany dziesiątkami lat karygodnego zaniedbania w kapitalistycznym ustroju i jego, także i pod tym względem, rabunkowej gospodarki. Dziś więc stoi przed nami ogromne zadanie doprowadzenia naszych rzek do stanu normalnego. Jest to na Śląsku zadanie tym ogromniejsze, że w lawinowym rozwoju naszego przemysłu i zaludnienia naszej części kraju w Planie 6-letnim, rosna także niemal z dnia na dzień ilości ścieków, z którymi musimy sobie poradzić i to w sposób jak najbardziej planowy i racjonalny"6.

Jak wskazuje cytowany artykuł (i nieliczne inne, referujące wyniki sporadycznie wykonywanych badań), fatalny stan czystości rzek nie był czymś zupełnie pomijanym. Możemy raczej mówić o niedocenianiu

5 J. Wierzbicki, Zanieczyszczenie rzek miejskimi i przemysłowymi wodami ściekowymi, „Gazeta Obserwatora PIHM”, t. 2, 1949, nr 10, s. 1-3.

6 A. Joszt, Ochrona rzek, „Gaz, Woda i Technika Sanitarna” 1952, nr 1, s. 21-24.

7 Zob. m.in.: I. Cabejszek, Z. Malanowski, S. Włodek, Zanieczyszczenie rzeki Bzury, „Gaz, Woda i Technika Sanitarna” 1952, nr 6, s. 162-167. Autorzy tego artykułu stwierdzali co prawda, że „Poniżej Zgierza stan zanieczyszczenia rzeki Bzury ulega gwałtownemu pogorszeniu pod wpływem ścieków z zakładów przemysłowych, znajdujących się na terenie tego miasta. Rzeka zmienia zupełnie swój charakter, stając się po prostu kanałem ściekowym”, ale „Mimo to jej stan na odcinku ok. $100 \mathrm{~km}$ aż do ujścia do Wisły nie jest zły". 
tej kwestii, jej bagatelizowaniu. Czy prymat rozwoju przemysłu, romantyzm wielkiej industrializacji nakazywał minimalizowanie takich „trudności wzrostu" jak ta, wyciszanie i unikanie podejmowania dyskusji na ten temat?

Próba udzielenia odpowiedzi na to pytanie jest o tyle skomplikowana, że nie dysponujemy jeszcze odpowiednimi badaniami szczegółowymi. To, co dało się ustalić na podstawie kwerend zwykle utajnionych dokumentów zawartych w zespołach archiwalnych centralnych instytucji państwa(partii) świadczy, że ślady początków dyskursu na ten temat datuja się na przełom lat 40. i 50. Wskazuje na to zachowane w aktach stalinowskiego superministerstwa - Państwowej Komisji Planowania Gospodarczego (PKPG) sprawozdanie z działalności Międzywojewódzkiego Komitetu Ochrony Rzek w Katowicach za rok $1951^{8}$. Wynika z niego, że powołania takiej placówki domagał się przede wszystkim świat rybacki, bo spośród fauny „ryba jest pierwszym sygnalizatorem, że woda jest zła”. Komitet, początkowo finansowany przez samorządy w Katowicach i Krakowie oraz zainteresowane ministerstwa (Górnictwa i Energetyki, Odbudowy, Rolnictwa i Administracji Publicznej), z czasem otrzymał kredyty z Ministerstwa Gospodarki Komunalnej (MGK). W 1951 r. w ramach MKOR istniały Placówki Naukowo-Badawcze w Krakowie i Katowicach oraz Komisja Naukowa. Z dniem 1 stycznia 1952 r. placówki i biura komitetu finansowane były z budżetów terenowych (Prezydiów Wojewódzkich Rad Narodowych w Katowicach i Krakowie). To w tych strukturach dokonano badań kilkudziesięciu zakładów przemysłowych i kilkuset kilometrów rzek stwierdzając liczne zaniedbania (brak oczyszczalni ścieków lub ich złe funkcjonowanie) ${ }^{9}$.

Z akt PKPG wynika również, że w jej strukturach został powołany (z dniem 1 czerwca 1951 r. na podstawie uchwały Prezydium Rządu nr 261 z 7 kwietnia 1951 r.) urząd Pełnomocnika Przewodniczącego PKPG do sprawy gospodarki woda pitna i przemysłowa. Powstały w tym samym roku Instytut Gospodarki Komunalnej miał kierować pracami tworzonych w całym kraju Placówek Naukowo-Badawczych Wojewódzkich Komitetów Ochrony Rzek ${ }^{10}$.

8 Archiwum Akt Nowych w Warszawie (dalej: AAN), Państwowa Komisja Planowania Gospodarczego (dalej: PKPG), sygn. 6661, Sprawozdanie rzeczowe Sekretarza Międzywojewódzkiego Komitetu Ochrony Rzek w Katowicach za rok 1951, bp.

9 Tamże, Sprawozdanie rzeczowe..., bp.; tamże, Sprawozdanie z działalności Placówki Naukowo-Badawczej Międzywojewódzkiego Komitetu Ochrony Rzek przed zanieczyszczeniem w Krakowie za rok 1951, bp.

10 Tamże, Sprawozdanie rzeczowe..., bp. 
W tym okresie zanieczyszczenie wód bywało również problemem w stosunkach zagranicznych. Co jakiś czas służby dyplomatyczne Polski i państw ościennych (chyba przede wszystkim czechosłowackie) informowały się wzajemnie o zatruciach rzek granicznych wywołanych przez ścieki zakładów przemysłowych ${ }^{11}$.

Jak wynika z tej analizy ochrona wód w tym okresie była przedmiotem zainteresowania różnych struktur organizacyjnych. Do tych wskazanych wcześniej należy dodać odpowiednie komórki w ministerstwach przemysłowych, choć niewiele wiemy o zakresie i skuteczności ich działania.

Stalinowski dyskurs o zanieczyszczeniach środowiska naturalnego był wątły, ograniczony do wąskiego grona najwyższych władz partii i państwa oraz specjalistów. Problem był im znany, ale w polityce gospodarczej marginalizowany.

Wskazują na to chociażby zapóźnienia i zaniedbania legislacyjne. W okresie stalinowskim nadal obowiąywała ustawa wodna z 19 września 1922 r. (Dz.U. z 1928, nr 62, poz. 574; tekst jednolity z 1934 r. nr 110, poz. 976, z 1947 - nr 32, poz. 142 , z 1950 - nr 10 poz. 108 i z 1952 - nr 18, poz. 110). Brakowało do niej zarządzeń wykonawczych. Ustawa była oceniania jako w zasadzie martwa litera prawa. Obowiazywało również po wojnie rozporządzenie Prezydenta RP z 16 marca 1928 r. o usuwaniu nieczystości i wód opadowych (Dz.U. z 1939 r., nr 90, poz. 581 i z 1948, nr 44, poz. 317). Określało ono obowiązki (po nowelizacji) rad narodowych w tym zakresie, obciążając je powinnościa budowy urządzeń kanalizacyjnych i oczyszczania ścieków. Niektóre problemy ochrony wód regulowały: ustawa z 7 marca 1932 r. o rybołówstwie (Dz.U. nr 35, poz. 357) i ustawa o ochronie przyrody z 7 kwietnia 1949 r. (Dz.U. nr 25, poz. 180). Najważniejszą powojenną regulację tej problematyki stanowiło rozporządzenie Ministra Gospodarki Komunalnej z 2 września $1950 \mathrm{r}$. w sprawie określenia warunków, jakim powinny odpowiadać ścieki wpuszczane do zbiorników wód powierzchniowych i do ziemi (Dz.U. nr 41, poz. 371). Do czasu jego wydania nie było polskich przepisów dotyczących dopuszczalnego zanieczyszczenia wód powierzchniowych i ziemi oraz wymaganego oczyszczania ścieków. Na jego podstawie wprowadzono kategorie czystości wód powierzchniowych (I-IV) i ustalono, kto miał prawo zwalniania z niektórych rygorów ustawy wodnej. To w tym rozporządzeniu po raz pierwszy zdefiniowano

${ }_{11}$ Zob. np. AAN, PKPG, sygn. 6305, Ambasada CSR w Warszawie do MSZ [1951], bp.; tamże, Tłumaczenie noty ambasady Czechosłowacji w Warszawie do polskiego MSZ [1952], bp. 
pojęcie ścieków ${ }^{12}$. W powszechnej opinii zainteresowanych resortów nie było ono przestrzegane - tak jak wiele innych aktów prawnych (i to nawet przez przedsiębiorstwa podległe resortowi, który je wydał) ${ }^{13}$.

\section{Destalinizacja: poszerzenie pola dyskursu}

Aktywność władz w zakresie stawiania problemu zanieczyszczenia środowiska i prób jego rozwiązania wzrosła wraz z destalinizacja.

Przede wszystkim coraz częściej różne instytucje prowadziły badania, których wyniki pokazywały skalę zagrożenia. Oto np. w 1957 r. na forum Międzyresortowej Komisji do spraw Odfenolowania Ścieków Przemysłowych zostało przedstawione studium, przygotowane w Centralnym Zarządzie Przemysłu Hutniczego, na podstawie danych zebranych z 260 zakładów odprowadzających tego typu ścieki. Wynikało $\mathrm{z}$ niego, że co najmniej 30\% zawartych w nich fenoli trafiało do zbiorników publicznych. Szczególnie dużo tych zatrutych ścieków odprowadzały koksownie i zakłady przerobu smoły. 9,8\% produkowanych fenoli wpuszczano bezpośrednio do rzek w zlewni Wisły, do zlewni Odry - aż $46,7 \%$, a do innych zlewni - niemal $100 \%{ }^{14}$.

O stanie zatrucia rzeki Odry mogli przekonać się posłowie, którzy uczestniczyli w pracach Nadzwyczajnej Komisji Ziem Odzyskanych, działajacej w sejmie w latach 1957-1961. Powstałe na jej zamówienie opracowania pokazuja ogrom dewastacji. „Dopływy Odry - stwierdzano w dokumencie przygotowanym dla NKZZ - sa zupełnie zniszczone przez przemysł. Odra, która przy niskich stanach wody traci

${ }^{12}$ „Za ścieki w rozumieniu niniejszego rozporządzenia uważa się wszelkie wody zużyte oraz te wody opadowe, które sa ujęte w przewody otwarte lub zakryte i sa odprowadzane osobno lub łącznie z wodami zużytymi z osiedli bądź z poszczególnych nieruchomości. Do wód zużytych zalicza się również wody od chłodzenia urządzeń”. Zob. Rozporządzenie Ministra Gospodarki Komunalnej z 2 września 1950 r. w sprawie określenia warunków, jakim powinny odpowiadać ścieki wpuszczane do zbiorników wód powierzchniowych i do ziemi, Dz.U. 1950, nr 41, poz. 371.

${ }_{13}$ AAN, Ministerstwo Żeglugi i Gospodarki Wodnej (dalej: MŻiGW), sygn. 156, Inż. Jan Krysiński, Ustawodawstwo o ochronie wód przed zanieczyszczeniem, Warszawa, 4 VI 1958, bp.; AAN, MŻiGW, sygn. 59, Cz. Wdowiak, Prawna ochrona wód przed zanieczyszczeniem w Polsce, Poznań 1960. Referat wygłoszony przez Autora na ogólnokrajowej naradzie pracowników służby wodno-prawnej województw w Rzeszowie, Poznań, luty 1960, bp.

${ }_{14}$ AAN, MŻiGW, sygn. 195, Międzyresortowa Komisja do spraw Odfenolowania Ścieków Przemysłowych, Studium nad ściekami zafenolowanymi z zakładów przemysłowych i usługowych Polski oraz sposobami oczyszczenia tych ścieków, opracował inż. Jan Biczysko, Centralny Zarząd Przemysłu Hutniczego, listopad 1957, bp. 
zdolność samooczyszczania się stała się głównym zbiornikiem ścieków”. W 1954/1955 stężenie amoniaku wyniosło $9 \mathrm{mg} / 1$ (10 razy powyżej normy). Wskaźniki zanieczyszczenia w 1955 r. wzrosły siedmiokrotnie w stosunku do 1946 r. W 1958 r. stan zanieczyszczenia ujścia Odry doprowadził do tego, że woda w wodociagach Szczecina stała się niezdatna do picia. „Obecnie dostarcza się ją w beczkowozach”. Stwierdzono, że „Utrzymanie obecnego tempa wzrostu zanieczyszczeń Odry i jej górnych dopływów nie tylko ograniczy rozwój przemysłu i miast, ale może doprowadzić w ciagu kilku lat do katastrofy istniejące miasta i przemysł rejonu Odry. Katastrofa ta może być groźniejsza w skutkach ekonomicznych, społecznych i politycznych niż wszystkie katastrofalne powodzie, z którymi walczono w ciagu ostatnich 200 lat przez zabudowę Odry i jej dorzecza"15.

O tym, że na zanieczyszczenie Odry i jej dopływów miały szczególny wpływ duże zakłady przemysłowe zaświadczała również odpowiednia informacja Wydziału Gospodarki Wodnej Prezydium Wojewódzkiej Rady Narodowej we Wrocławiu z czerwca 1959 r. Dokument ten zawiera informację, że na terenie tego województwa znajdowało się w końcu lat 50. około 500 zakładów przemysłowych, około 100 lecznictwa zamkniętego i ponad 100 miejscowości posiadających urządzenia wodno-kanalizacyjne, więc wody w większości rzek zanim „dopłyną do Odry sa kilkakrotnie używane. W zamian za pobraną wodą zakłady odprowadzają ścieki”. Największym „trucicielem” Odry były „bezsprzecznie” Nadodrzańskie Zakłady Przemysłu Organicznego (NZPO) „Rokita” w Brzegu Dolnym: „Nieoczyszczone ścieki «Rokity» w ilości ok. $1800 \mathrm{~m}^{3} /$ godz., zawierające kilkadziesiąt różnych związków chemicznych, w tym również trujące, powodują systematyczne niszczenie życia biologicznego rzeki Odry na bardzo dużym odcinku jej biegu". Stan ten uległ w latach 1956-1959 pogorszeniu, co było spowodowane zwiększeniem produkcji przez ten zakład i uruchomieniem nowych oddziałów, bez budowy urządzeń do oczyszczania ścieków. W latach 1956-1959 miało miejsce pod wpływem ścieków „Rokity” wielokrotne masowe śnięcie ryb w rzece. Były to zatrucia mające charakter katastrofy. Tylko 9-10 września 1956 r. spłynęło około 80 ton zatrutych ryb na odcinku długości ok. $100 \mathrm{~km}$. Nie było możliwości regeneracji życia biologicznego.

15 AAN, Kancelaria Sejmu PRL (dalej: KS), sygn. 179, Protokół z 12 posiedzenia NKZZ 14 marca 1958, k. 150-151v. Zob. również: AAN, MŻiGW, sygn. 165, Sprawozdanie z sesji wyjazdowej komisji sejmowych we Wrocławiu w sprawie zagospodarowania Odry, [14 III 1958], k. 151-158. 
Kolejnym pod względem skali trucicielem - tym razem rzeki Bóbr i jej dorzeczy - były Zakłady Przemysłu Celulozowego w Jeleniej Górze, które codziennie wypuszczały do rzeki razem ze ściekami ok. 40 ton masy papierowej ${ }^{16}$.

Zarówno stan zanieczyszczenia wód, jak i będący jego następstwem ich niedobór stanowił stałe zagrożenie epidemiologiczne. Wspomniany Brzeg Dolny nieprzypadkowo wykazywał skoncentrowanie chorób zakaźnych przenoszonych woda. Jak stwierdzono w notatce informacyjnej lekarza Jadwigi Juźwiakowej, przedstawionej na posiedzeniu NKZZ w 1959 r. „w ubiegłych latach także i inne zakłady przemysłowe powodowały epidemie duru brzusznego wśród ludności, np. Jeleniogórskie Zakłady Włókien Sztucznych «Celwiskoza», Cukrownia Stary Jawor". Legnica była wówczas endemicznym ogniskiem czerwonki, biegunki dziecięcej oraz innych chorób przewodu pokarmowego, w których niedobór wody powodował wybuchy epidemii. Szczególnie alarmująca sytuacja panowała w Kręsku niedaleko Brzegu Dolnego, gdzie ludność od 1953 r. skarżyła się na zanieczyszczenia wody w studniach, stawie i potoku. Badania wykazały zatrucie wody fenolem. U mieszkańców (szczególnie dzieci) stwierdzono anemię. Trucicielem okazały się NZPO „Rokita”, ale zarządzenia karne wobec zakładów w niczym nie zmieniły sytuacji zdrowotnej mieszkańców Kręska ${ }^{17}$.

Zanieczyszczenie rzek było problemem szczególnie trudnym w województwie katowickim. Według odpowiedniej informacji przedstawionej NKZZ w czerwcu 1959 r. niskie przepływy własne i wielka ilość odprowadzanych ścieków sprawiły, że rzeki tego województwa „przekształciły się w znacznej części w kanały ściekowe, tracąc zdolność samooczyszczania swych wód”, wpływając na pogorszenie się stanu czystości wód Wisły i Odry również poza Katowickiem ${ }^{18}$.

Z notatek i raportów szczegółowych, dotyczących poszczególnych miast wyłania się czarny obraz rzek przekształcających się w cuchnące ścieki. Urządzenia do ich oczyszczania albo nie istniały, albo były obliczone na znacznie mniejszą wielkość ścieków, albo były nieskuteczne ze

${ }^{16}$ AAN, KS, sygn. 180, Informacja o aktualnym stanie gospodarki wodnej województwa wrocławskiego ze szczególnym uwzględnieniem transportu wodnego. Załącznik do protokołu z 20 posiedzenia NKZZ w dniach 25-27 VI 1959, k. 58-59.

${ }_{17}$ AAN, KS, sygn. 180, Notatka informacyjna Jadwigi Juźwiakowej [1959], k. $71-78$.

18 Tamże, k. 19, Informacja o sytuacji gospodarki wodnej województwa katowickiego ze szczególnym uwzględnieniem dorzecza rzeki Odry oraz możliwości przedłużenia kanału gliwickiego. Załącznik do protokołu z 20 posiedzenie KNZZ w dniach 25-27 czerwca 1959, k. 18-19. 
względu na przestarzałą technologię. Prowadziło to do sytuacji grożącej wybuchem epidemii. W robotniczych Starachowicach w 1958 r. do rzeki Kamiennej wpuszczane były ścieki ze szpitala zakaźnego, blisko ujęcia wody dla miasta. Analizy wykazały bakterie tyfusu w sasiedztwie wylotu kanału ${ }^{19}$.

Alarmująca sytuacja była również w Gdyni. Miasto posiadało co prawda oczyszczalnię cieków, ale jej przepustowość dzienna wynosiła 9 tys. $\mathrm{m}^{3}$, podczas gdy w 1957 r. łączna ilość odprowadzanych ścieków wynosiła $4854934 \mathrm{~m}^{3}$. Biologicznego systemu oczyszczania ścieków miasto nie posiadało; częściowo tylko oczyszczone mechanicznie ścieki odprowadzane były do basenu portowego. W okresach szczytu, tj. przez cały dzień, około 50\% ścieków ze względu na przeciążenie komór przepływowych odprowadzano nawet bez mechanicznego oczyszczenia. Przepływająca przez Gdynię rzeka Kacza, która przyjmowała ścieki z okolicznych zakładów, była ogniskiem duru brzusznego. Wpadała do morza w rejonie jedynej plaży w dzielnicy Orłowo - niemożliwej z tego powodu do wykorzystania. Często zdarzało się, że surowe ścieki Gdyni trafiały wprost do basenu portowego. W 1955 r. wprowadzono do basenu ścieki z magazynu skór porażonych węglikiem ${ }^{20}$.

Wyniki badań, świadczące o katastrofalnym stanie zanieczyszczenia polskich rzek, coraz częściej były publikowane w czasopismach specjalistycznych $^{21}$. To wówczas pojawiły się tam rzeczywiste polemiki na temat tego, jak radzić sobie z zanieczyszczeniem środowiska przy ograniczonych środkach przeznaczonych na jego ochronę. O radykalizmie niektórych pomysłów niech świadczy artykuł Włodzimierza Skoraszewskiego pod symptomatycznym tytułem Rzeki czy ścieki? z 1956 r. ${ }^{22}$ „Wydaje się nam i zdanie nasze podziela jeszcze paru kolegów posiwiałych w bojach

19 AAN, Ministerstwo Gospodarki Komunalnej (dalej: MGK), sygn. 1/224, Ocena stanu bieżącego i rozwoju gospodarki komunalnej i mieszkaniowej woj. kieleckiego, [listopad 1958], k. 54.

${ }^{20}$ Tamże, sygn. 1/215, Sprawozdanie z kontroli stanu sanitarnego miasta Gdyni, przeprowadzonej w dniach od 13 do 15 X 1958 r. przez Ministerstwo Gospodarki Komunalnej, k. 12-27.

${ }_{21}$ Zob. m.in. S. Bontemps, W sprawie zanieczyszczeń wód, „Gospodarka Rybna” 1955, nr 2, s. 6-8; I. Cabejszek, B. Koziorowski, Z. Malanowski, J. Stanisławska, Charakterystyka higieniczno-sanitarna rzeki Wisty na odcinku Góra Kalwaria-Warszawa, „Gaz, Woda i Technika Sanitarna” 1956, nr 5, s. 175-181; F. Chrzanowski, Zanieczyszczenie wód śródladowych województwa gdańskiego, „Gospodarka Rybna” 1956, nr 7, s. 7-8; E. Zaczyński, Zanieczyszczenie rzek Górnoślaskiego Okregu Przemystowego, „Chrońmy Przyrodę Ojczysta” 1959, nr 4, s. 15-21; J. Goliszewski, Stan zanieczyszczenia wód powierzchniowych w Polsce, „Gospodarka Wodna” 1961, nr 10, s. 430-435. 22 „Gaz, Woda i Technika Sanitarna” 1956, nr 11, s. 405-406. 
o czystość naszych rzek, iż nie da się większości z nich uratować przed takim zanieczyszczeniem, które uniemożliwi korzystanie z ich wód dla celów użytkowych”. Co należy zrobić? „Nie możemy chyba zaniechać z tego powodu ambitnych zamierzeń rozwoju naszego przemysłu. Jest on fatalnie położony, bo w górnym biegu rzek głównych. Zanieczyszczenia masowe będą ciążyć na całym kraju. Jednocześnie względy surowcowe, tj. obfitość węgla, soli kuchennej, potasowej, i wapna decyduja o charakterze przyszłego rozwoju naszego przemysłu. Wielka chemia syntetyczna - oto przyszła królowa naszego życia gospodarczego i «wróg Nr 1» wód wszelkiego rodzaju. Stąd już krok tylko do wniosków zasadniczych. Musimy i to jak najprędzej rozdzielić nasze rzeki i strumienie na dwa rodzaje zasadnicze: I. Nadające się do utrzymania w czystości, jako źródła wody komunalnej i zdatnej do użytku wymagającego wody czystej według dzisiejszych poglądów. II. Niemożliwe do ocalenia”. Autor tego tekstu posłużył się przykładem stolicy: „Warszawa bierze wodę z Wisły. Wisła za lat 30-50 będzie prowadziła ciecz podobna do tego, co płynie Nerem poniżej Łodzi. Oczywiście substancja tego rodzaju nie da się oczyścić do stanu zdatnego do picia. A gdyby nawet, to smak tego produktu nie pozwoli na jego używanie. Wobec tego pozostaje tylko Bug i Narew, jako źródło zaopatrzenia stolicy w przyszłości, a także miast leżących poniżej Warszawy i w pobliżu Wisły, a z niej wodę dotychczas czerpiących. Jednakże będzie to możliwe o tyle, o ile ochronimy zlewnie rzek wspomnianych przed lokalizacja tam przemysłu, mogącego mieć wpływ szkodliwy na czystość tych wód”.

W specjalistycznych periodykach można było również odnaleźć wcześniej pomijane informacje na temat rzeczywistego stanu oczyszczalni ścieków w Polsce. Tadeusz Tatko w 1958 r. twierdził ${ }^{23}$, że z około $12 \mathrm{mln}$ Polaków żyjących w miastach około 6 mln korzystało z kanalizacji miejskiej. Na ogólną liczbę ok. 464 miast skanalizowanych, oczyszczalnie czynne posiadało 148 , nieczynne -30 , w budowie -9 , a 5 miast posiadało oczyszczalnie czynne rozbudowujące się. Według stanu w roku 1956 - 40 miast posiadajacych sieć wodociagowa nie miało kanalizacji. W Polsce liczba miast posiadających sieć kanalizacyjna, ale pozbawionych oczyszczani ścieków, wynosiła według niego: 200 - o wielkości do 10 tys. mieszkańców, $44-10-20$ tys. mieszkańców, $23-20-50$ tys., $8-50-100$ tys., $3-100-200$ tys., 2 - powyżej 200 tys. $55 \%$ oczyszczalni miało charakter mechaniczny, co zmniejszało jakość oczyszczania ścieków. Pozostałe 45\% oczyszczalni mechaniczno-biologicznych

${ }_{23}$ T. Tatko, Obecna sytuacja oczyszczalni ścieków w Polsce, „Gaz, Woda i Technika Sanitarna" 1958, nr 9, s. 342-344. 
pracowało z reguły niedostatecznie bądź z powodu przeciążenia, bądź złej eksploatacji. Dobrze pracujace oczyszczalnie biologiczne posiadały tylko trzy miasta: Świdnica, Gdańsk, Kielce, ale nawet one „oddawały" w części ścieki źle oczyszczone z powodu niewydolności urzadzeń. Około 80\% oczyszczalni mechanicznych wzniesiono w latach 1900-1940, w tym czasie powstało również ok. 70\% oczyszczalni biologiczno-mechanicznych. W latach 1941-1957 zbudowano tylko kilka (prowizoryczna w Otwocku, w Ursusie, Gołąkkach, Pruszkowie, Sandomierzu, Świdniku, Poniatowej, Mielcu, Strumieniu, Skoczowie i Świdnicy). Autor artykułu ujawniał przypadki rażąco złego funkcjonowania i zaniedbań w pracy oczyszczalni. W Pruszkowie w ciagu trzech lat po oddaniu do użytku - oczyszczalnia czynna była zaledwie trzy miesiace z powodu... braku gospodarza. Kierownik Powiatowego Przedsiębiorstwa Gospodarki Komunalnej w Sztumie nie wiedział, co to oczyszczalnia ścieków, toteż była ona nieczynna, a ścieki wpływały bezpośrednio do Jeziora Sztumskiego. Część tych obiektów wymagała tylko drobnych remontów, których nie wykonywano i w rezultacie nie działały.

Tematem dyskursu w tym okresie, toczącego się przede wszystkim w gronie ludzi władzy i specjalistów, były również problemy skuteczności stosowanych środków organizacyjnych i rozwiązań prawnych ${ }^{24}$.

Przede wszystkim za celowe uznano powołanie nowych urzędów zajmujących się ochroną elementów środowiska naturalnego. Najważniejsze z nich miały zajmować się wodami powierzchniowymi. Już w 1954 r. powołano do życia Państwową Inspekcję Ochrony Wód (PIOW), podporządkowaną MGK ${ }^{25}$. Na mocy ustawy z 28 maja $1957 \mathrm{r}$. powstał Urząd Ministra Żeglugi i Gospodarki Wodnej (Dz.U. nr 31, poz. 130), który miał m.in. zająć się „,sprawowaniem nadzoru nad ochrona wód przed zanieczyszczeniem oraz nad całokształtem gospodarki ściekowej”26. Podporządkowano mu w 1959 r. PIOW ${ }^{27}$. Stworzono podstawy kadrowe dla ochrony wód w terenie w postaci pracowników siedemnastu wojewódzkich i dwóch miejskich inspekcji ochrony wód oraz kilkunastu laboratoriów wody i ścieków. Wreszcie w 1960 r. utworzono

${ }^{24}$ Zob. m.in.: J. Trendota, W sprawie właściwych metod ochrony wód przed zanieczyszczeniem ściekami, „Gaz, Woda i Technika Sanitarna” 1956, nr 4, s. 142-143.

${ }_{25}$ Uchwała Prezydium Rządu nr 436 z 7 VII 1954 r. o Państwowej Inspekcji Ochrony Wód (MP nr A-69, poz. 863); Zarządzenie Ministra Gospodarki Komunalnej z 29 X 1954 w sprawie organizacji, szczegółowego zakresu działania oraz zasad i trybu postepowania Państwowej Inspekcji Ochrony Wód (MP nr 119, poz. 1680).

${ }^{26}$ AAN, MŻiGW, sygn. 156, Ustawa z dnia 28 V 1957 o utworzeniu urzędu Ministra $\dot{Z} i G W$, bp.

27 Tamże, Inż. Jan Krysiński, Ustawodawstwo... 
Instytut Gospodarki Wodnej, w skład którego wszedł Centralny Zakład Ochrony Wód we Wrocławiu i pięć podległych mu terenowych zakładów. Uwieńczeniem tych przemian organizacyjnych było utworzenie w 1960 r. Centralnego Urzędu Gospodarki Wodnej (CUGW) jako naczelnego organu administracji, podporządkowanego bezpośrednio Prezesowi Rady Ministrów ${ }^{28}$.

Najwięcej kontrowersji w strukturach rządowych wywoływało jednak stanowienie nowego prawa w zakresie ochrony wód przed zanieczyszczeniem.

23 czerwca 1954 r. zostało wydane niepublikowane zarządzenie nr 147 prezesa Rady Ministrów w sprawie zastosowania środków zapobiegawczych zanieczyszczeniu ściekami wód powierzchniowych. Stwierdzając częste nieprzestrzeganie obowiązujących przepisów, dotyczących warunków, jakim powinny odpowiadać ścieki, premier zobowiąał ministrów, którym podlegają zakłady produkujące ścieki, do wydania zarządzeń zapewniających przeprowadzenie gruntownego przeglądu urządzeń oczyszczających ścieki i doprowadzenie ich do pełnej wydajności oraz ustanowienia systemu kontroli nad ściekami z codziennym badaniem chemicznym. Zarządzenie zwracało uwagę na konieczność przestrzegania postanowień rozporządzenia MGK z 2 września1950 r. w sprawie określenia warunków, jakim powinny odpowiadać ścieki wpuszczone do wód powierzchniowych i do ziemi ${ }^{29}$. W załączniku do zarządzenia zamieszczono wykaz zakładów, których ścieki były przyczyną najpoważniejszych zanieczyszczeń wód Wisły. Znalazło się na nim trzynaście kopalni, jedenaście hut, trzy zakłady cynkowe, dwie rafinerie nafty, dwie fabryki celulozy i papieru, dwa zakłady chemiczne i jeden kokso-chemiczny ${ }^{30}$.

20 sierpnia 1955 r. została wydana uchwała nr 668 Prezydium Rządu w sprawie ochrony wód przed zanieczyszczeniem oraz zapobiegania szkodliwemu działaniu ścieków i ich gospodarczego wykorzystania. Ministrowie, którym podlegały zakłady pracy odprowadzajace ścieki, zostali zobowiązani do należytego rozwiązania zagadnienia ich oczyszczania w ramach ich resortów. Uchwała stanowiła, że projektowanie budowy, przebudowy albo modernizacji lub rozbudowy zakładów pracy odprowadzających ścieki do wód powierzchniowych, bez

${ }^{28}$ J. Krysiński, Węzłowe problemy ochrony czystości wód (organizacyjne, techniczno-ekonomiczne i prawne), „Gospodarka Wodna” 1961, nr 10, s. 416-420.

${ }^{29}$ AAN, MŻiGW, 156, Inż. Jan Krysiński, Ustawodawstwo...

30 Tamże, Wykaz zakładów, których ścieki są przyczyną najpoważniejszych zanieczyszczeń wody rzeki Wisły, bp. 
racjonalnego rozwiązania zagadnienia oczyszczania zabezpieczającego przed szkodliwym działaniem ścieków, jest niedopuszczalne ${ }^{31}$.

Najwięcej kontrowersji wśród zainteresowanych władz wzbudził jednak projekt ustawy o ochronie wód przed zanieczyszczeniem. Zagadnienie to, zgodnie z poleceniem Prezesa Rady Ministrów z 3 czerwca 1959 r., zostało wyłączone z nowo opracowywanego projektu prawa wodnego i jako pilne potraktowane oddzielnie w osobnym akcie prawnym. Projekt ustawy był przedmiotem obrad rządu 31 grudnia 1959 r., gdzie wzbudził „zasadnicze zastrzeżenia”, zwłaszcza ministra przemysłu lekkiego. Poddano go po raz kolejny konsultacjom, wraz z projektami aktów wykonawczych. Swoje krytyczne uwagi zgłosiła wówczas: Komisja Planowania przy Radzie Ministrów, Ministerstwa: Przemysłu Lekkiego, Zdrowia i Opieki Społecznej, Żeglugi, Gospodarki Komunalnej, Finansów, Sprawiedliwości, Prokuratura Generalna oraz Komitet Budownictwa, Urbanistyki i Architektury. Po wielu dyskusjach ustawa została uchwalona 31 stycznia 1961 r. (Dz.U. nr 5, poz. 33). $\mathrm{Na}$ jej podstawie wydane zostało rozporządzenie Prezesa Rady Ministrów z 28 lutego 1962 r. określające dopuszczalne normy zanieczyszczeń oraz warunki, jakim powinny odpowiadać ścieki odprowadzane do wody i do ziemi ${ }^{32}$.

Co było przedmiotem kontrowersji, które przedłużyły proces legislacyjny? Wymaga to dalszych badań, ale odnalezione materiały źródłowe i opracowania wskazuja, że najwięcej różnic zdań powodowały przewidziane $\mathrm{w}$ rozwiązaniach prawnych obowiązki nakładane na zakłady pracy w zakresie budowy urządzeń do oczyszczania ścieków oraz kary nakładane na trucicieli.

Uzasadnienie dla nowego aktu prawnego miało przede wszystkim charakter ekonomiczny. CUGW szacował, że straty powodowane dotychczasową gospodarką ściekową i zanieczyszczeniem wód wynosiły $2-3$ mld zł rocznie. Przyczyną takiego stanu rzeczy miały być m.in. obowiązujące przepisy, zawarte w dziewięćdziesięciu kilku aktach normatywnych wydanych w latach 1922-1956. W'śód nich podstawowe znaczenie miała ustawa wodna z 1922 r. oraz wspomniane wcześniej rozporządzenie MGK z 2 września 1950 r. Zwracano uwagę, że stara ustawa wodna nie obejmowała przybrzeżnych wód morskich, wiele jej postanowień nie odpowiadało nowym warunkom ustrojowym,

${ }^{31}$ Tamże, Inż. Jan Krysiński, Ustawodawstwo...

${ }^{32}$ W. Brzeziński, dz. cyt., s. 155-159; AAN, MŻiGW, sygn. 60, Notatka w sprawie projektu ustawy o ochronie wód przed zanieczyszczeniem, Warszawa, 18 X 1960 [CUGW], bp. 
a przewidziane środki represyjne $\mathrm{w}$ „świetle wielokrotnych doświadczeń" okazały się jedynie martwa litera prawa.

Według opinii CUGW przepisy obowiązujące do 1961 r. były wyrazem poglądu, że wszelkie skażenie przekraczające miarę powszechnego użytkowania wód było szkodliwe i niedopuszczalne; wynikające z nich wymagania odnośnie do stopnia oczyszczania ścieków i czystości wód były raczej jednostronnym wyrazem potrzeb, szczególnie higieniczno-sanitarnych, bez uwzględnienia możliwości technicznych i ekonomicznych. Wymagania dotyczace dopuszczalnych ilości i składu substancji zanieczyszczających były jednakowe bez względu na aktualny stan czystości odbiornika i koszty redukcji ładunków zanieczyszczeń, zawartych w poszczególnych rodzajach wód użytkowych. Rygorystyczne i nieżyciowe wymagania obowiązujących do $1961 \mathrm{r}$. przepisów - twierdzili urzędnicy CUGW - powodowały nie tylko często nieproporcjonalny do efektów wzrost kosztów budowy urządzeń, lecz również nierzadko stwarzały niepokonane dotychczas trudności w zakresie rozwiązań technicznych.

Nowa ustawa hołdować miała innym zasadom. Celem ochrony wód przed zanieczyszczeniem miało być zachowanie lub przywracanie ich odpowiedniej przydatności. Jako zanieczyszczenie rozumiano w niej bezpośrednie lub pośrednie zmiany składu lub stanu wody, wynikające z działalności człowieka i powodujące zmniejszenie lub zniweczenie jej przydatności dla poszczególnych lub wszystkich celów, ze szkodą dla dobra ogólnego. Wobec przeciwieństwa interesów i potrzeb użytkowników wody i dążeń „producentów” zanieczyszczeń, ustawa uprawniała do rozwiązań kompromisowych, „teoretycznie niedoskonałych”, lecz praktycznie optymalnych z puntu widzenia gospodarczego i społecznego. Zgodnie $\mathrm{z}$ tą filozofia plany ochrony wód powinny uwzględniać realne możliwości techniczne i ekonomiczne oczyszczania ścieków oraz oczywiste aktualne potrzeby użytkowników zasobów wodnych. Zdecydowano, że kwestie szczegółowe, dotyczące np. ustalenia norm dopuszczalnych ilości, stanu i składu substancji zanieczyszczających, które może zawierać woda będa przedmiotem osobnych aktów wykonawczych ${ }^{33}$.

W komentarzach do ustawy podkreślano, że punktem wyjścia tego aktu prawnego jest „generalne założenie jej realności”. Nie stawia ona „teoretycznie uzasadnionych wymagań zachowania lub przywrócenia absolutnej czystości wód, lecz tylko przydatności wód do ich wykorzystania na konkretne cele, co pozwoli na dostosowanie stopnia obciążenia odbiornika ściekami do jego rodzaju i ponownego sposobu 
wykorzystania”. Jedynie w niektórych przypadkach Rada Ministrów mogła zakazać odprowadzania jakichkolwiek substancji zanieczyszczających. „Innymi słowy poza wyjątkowymi zakazami całkowitego wpuszczania ścieków, podyktowanymi specjalnymi względami, ustawa zakazuje jedynie szkodliwego zanieczyszczania wód. Przeto bez utrudnień będą wpuszczane ścieki, które wprawdzie wodę zanieczyszczaja, lecz zanieczyszczenie to nie przekroczy wymaganego stopnia czystości wody dla danej zlewni lub obszaru wodnego" ${ }^{34}$.

Ustawa zobowiazywała zakłady pracy do uzgodnienia z wydziałem gospodarki wodnej PWRN założeń i projektów wstępnych budowy, rozbudowy lub przebudowy zakładu. Uzgodnieniem objęte miały być warunki oczyszczania ścieków. Ustawa zobowiązywała inwestora do opracowania dokumentacji projektowo-kosztorysowej urządzeń do wykorzystania, oczyszczania, unieszkodliwiania i odprowadzania ścieków, łącznie z dokumentacją projektowo-kosztorysową budowy zakładu. Bez nich nie wolno było inwestorowi zatwierdzić założeń ani projektu wstępnego zakładu. Ustawa wprowadziła sankcje karne za zanieczyszczenie wód - grzywny, a nawet kary więzienia. Zakłady, które nie posiadały urządzeń zabezpieczających przed zanieczyszczeniem wód lub posiadały urządzenia częściowe poddane miały być rygorom ustawy sukcesywnie, w miarę zamieszczania ich w wykazach ustalonych przez Radę Ministrów na wniosek prezesa CUGW, zgłoszony w porozumieniu z Komisją Planowania przy RM. Rada Ministrów miała ustalać rodzaje urządzeń, w jakie zakłady te powinny być zaopatrzone oraz terminy ich wykonania ${ }^{35}$.

Aktywność legislacyjna była niezwykle ważna, ale z punktu widzenia badania dyskursu o degradacji środowiska zbytnio go nie poszerzała. Rozwiązania prawne były przedmiotem rozważań w gronie ludzi władzy oraz ekspertów i znajdowały odzwierciedlenie w często utajnionych dokumentach oraz co najwyżej niszowych, specjalistycznych periodykach.

To co mogło rzeczywiście wpłynąc na świadomość społeczną w tym zakresie, to była publicystyka na łamach prasy codziennej i periodyków kierowanych do szerokiego kręgu odbiorców.

Początkowo „odwilż” polityczna nie owocowała w tym przypadku niczym spektakularnym. Publicystyka lat 1954-1955 wyraźnie nie „odkryła” jeszcze tego problemu. Pisano co prawda o miejskich ściekach, ale nacisk kładziono na poszukiwanie nowatorskich rozwiązań ich

${ }_{34}$ S. Surowiec, Uwagi do ustawy o ochronie wód przed zanieczyszczeniem, „Gospodarka Wodna” 1961, nr 10, s. 426-427.

35 Tamże, s. 426. 
oczyszczania ${ }^{36}$. Sposób przedstawiania problemów zanieczyszczonych wód niewiele różnił się od dominującego w okresie wcześniejszym ${ }^{37}$.

Stopniowo jednak akcenty zaczęły się zmieniać i również w prasie codziennej zaczęto pisać o skali zagrożenia. W 1956 r. w „Życiu Warszawy" Tadeusz Borowy przedstawił wyniki badań i plan gospodarki wodnej przygotowany przez Komitet Gospodarki Wodnej PAN. Przewidywał on potrzebę wybudowania do roku 1975 piętnastu zbiorników retencyjnych o objętości $450 \mathrm{mln} \mathrm{m}^{3}$ oraz ujęć wody i urządzeń dla przemysłu w ilości około $2,8 \mathrm{mln}^{3}$ na dobę, na łączną odległość $560 \mathrm{~km}$. W przypadku małych miast, wsi i lokalnych zakładów przemysłowych - liczyć się należało z okresami deficytów wody w okresach po suszach, szczególnie w GOP i w dolinie rzeki Kamiennej. Szacunki do 1975 r. wskazywały, że zanieczyszczenie ściekami będzie większe niż $\mathrm{w} 1950 \mathrm{r}^{38}$

W prasie codziennej duże kontrowersje budził lansowany jeszcze w stalinizmie sposób używania ścieków do nawożenia użytków rolnych. Leon Lenar na łamach „Życia Warszawy” po pierwsze wskazywał, że ta koncepcja ma swoich przeciwników, a po drugie - protestował przeciwko projektom założenia melioracji ściekowych w okolicach Kampinoskiego Parku Narodowego. Twierdził nie bez słuszności, że może to zniszczyć walory przyrodnicze i przyrodnicze parku i podnieść wody gruntowe. „Niewatpliwe i higieniści będą mieli zastrzeżenia, bo jak wynika z niemieckich doświadczeń, stan zdrowia ludności korzystajacej z płodów rolnych wyprodukowanych na gruntach nasycanych ściekami trzeba często kontrolować. Są wypadki zarobaczywienia jelit i nie wiadomo, jakie skutki wywierać będą wirusy, które maja zdolność przenikania do roślin. Jarzyn z powodu «zapachu» nie będzie można produkować. Czy zatem wprowadzenie na wielką skalę takich melioracji pod milionowym miastem, którego mieszkańcy będą spożywać produkty wyhodowane na ściekach, jest pożądane? Za najlepsze

${ }_{36}$ Zob. m.in.: M. Szczerbińska, Woda dla Warszawy, „Tygodnik Demokratyczny” 1955, nr 40, s. 7; T. Keller, Problem zdrowej wody, „Tygodnik Demokratyczny” 1955, nr 49 , s. 7.

${ }^{37}$ E. Zajdel, Ochrona czystości wód ważnym czynnikiem w gospodarce narodowej, „Życie Gospodarcze” 1954, nr 8, s. 305-306. Autor pisał: „Zagadnienie ochrony ich czystości stało się palącym zagadnieniem na terenie woj. stalinogrodzkiego, gdzie, poza specyficznym zagęszczeniem ludności i przemysłu, wymagał szybkiej poprawy w tym zakresie stan czystości rzek ślaskich, spowodowany dziesiątkami lat karygodnego zaniedbania istniejącego w warunkach ustroju kapitalistycznego. Nadto poszerzyła tu jeszcze to zagadnienie sprawa olbrzymiego rozwoju naszego przemysłu w okresie planu 6-letniego i związany z tym stały wzrost ilościowy odpływów fabrycznych".

${ }^{38}$ T. Borowy, Nasze kłopoty z woda $i$ ściekami, „Życie Warszawy” 1956, nr 82, s. 4. 
rozwiązanie uważają rzecznicy ochrony przyrody budowę pełnej oczyszczalni ścieków, która zapewniłaby wykorzystanie części stałych do celów rolniczych, choć przy zmniejszonej już nieco wartości odżywczej dla roślin" ${ }^{39}$.

Wyrazem zaniepokojenia skutkami i tempem zanieczyszczenia polskich rzek był zamieszczony w „Życiu Warszawy” w 1958 r. artykuł Jerzego Jaruzelskiego Otrute $r z e k i^{40}$. „Bodaj ze dwa lata temu - pisał jego autor - zepsuła się woda w Krakowie. Niedawno szczecinianie przestali pić wodę z miejskiej sieci i stanęli z kubełkami w ogonkach przy starych studniach. Ostatnio również woda z mieleckich wodociagów nie nadaje się do spożycia. Krakowski skandal zażegnano kosztem 40 milionów złotych, budując nowe ujęcie wody z Rudawy. W Szczecinie - dzięki pomocy Politechniki - zakłada się pochłaniacze, które maja eliminować zanieczyszczenia fenolowe, przy pobieraniu wody z Odry. Do Mielca wyjechali specjaliści, aby ratować sytuację...”. Autor ostrzegał, że następną ofiarą tego typu trudności stanie się Warszawa. Już 1956 r. pojawiły się pierwsze symptomy „złej wody” w stolicy. Twierdził, że groźba kryzysu jakości wody w Warszawie zwiększy się z chwila uruchomienia kombinatu siarkowego w Tarnobrzegu. Według cytowanego w artykule Jana Krysińskiego, dyrektora PIOW przy MŻiGW, „Wisła, począwszy do Przemszy jest właściwie kanałem ściekowym”. „Zatem granica Wisły - kanału ściekowego i Wisły - rzeki nieustannie zbliża się do Warszawy". Nasze władze - utrzymywał Jaruzelski - nie były formalnie i materialnie przygotowane do rozwiązania tej sprawy. PIOW to bezsilny organ, nieposiadający nawet środków i możliwości,

${ }^{39}$ L. Lenar, Park narodowy czy ścieki, „Życie Warszawy” 1956, nr 66, s. 8. O tym, że pomysł nawożenia pól wodami ściekowymi również po $1956 \mathrm{r}$. miał swoich zagorzałych zwolenników świadczy artykuł Zbigniewa Cyranowicza Złoto mętnych wód (,Trybuna Ludu” 1960, nr 219). Jego autor pisał: „Zjawisko znane od dawna. Rzeki nasze sa siedliskiem różnego rodzaju zarazków zanieczyszczających wodę, glebę i powietrze, utrapieniem ludzi, zagładą dla ryb. Ścieki miejskie i przemysłowe - bo o nie właśnie chodzi - zamieniły wiele naszych rzek w cuchnące kanały”. Według badań w 1960 r. miało spłynąć do potoków, rzek i jezior w Polsce $3 \mathrm{mld}^{3}$ ścieków. „Czy nie można temu zapobiec? Jak dotąd robimy co tylko możliwe”. Autor twierdził, że ukazało się wiele resortowych zrządzeń, specjalna uchwała Prezydium Rządu. Wszystkie zakazuja odprowadzania ścieków do wód. Pociaga to za sobą konieczności budowy sztucznych oczyszczalni. Według naukowców na tego typu inwestycje potrzeba ponad $25 \mathrm{mld}$ zł. Cyranowicz pytał: „Czy nie ma innych rozwiązań? I odpowiadał: są: „ścieki zamiast strat moga przynosić ogromne korzyści”. Zawierają bogactwo pokarmów i substancji organicznych: „Wody ściekowe mogą nawozić glebę i wzbogacić ja w próchnicę, stać się bez przesady decydującym czynnikiem wzrostu plonu”, co miały potwierdzać badania prof. Jana Wierzbickiego z Akademii Rolniczej we Wrocławiu.

${ }^{40}$ J. Jaruzelski, Otrute rzeki, „Życie Warszawy” 1958, nr 52, s. 3-4. 
aby na bieżąco rejestrować stan zanieczyszczeń wód choćby w głównych punktach. Prawo wodne z 1922 r. było całkowicie nierealne i niestosowane, zwłaszcza $\mathrm{w}$ swych $\mathrm{w}$ najistotniejszych punktach określających warunki i ewentualną odpowiedzialność za zanieczyszczenia rzek. Z tej przyczyny, nie zaś tolerancyjności sądów czy łagodności prokuratury, wynikło odrzucenie 26 , czyli wszystkich spraw przeciwko dyrektorom przedsiębiorstw państwowych odpowiedzialnych za trucie wód. „Odpowiedzialność karna nie istnieje więc, natomiast roszczenia cywilne wysuwane szczególnie przez zespoły rybackie na ogół sa honorowane”. Według ustaleń autora zakłady „Rokita” w Brzegu Dolnym zapłaciły rybakom tylko w 1957 r. 640 tys. zł za niszczenie rybostanu. Jak twierdzili „ochroniarze” (pracownicy PIOW), „fabryce lepiej kalkuluje się płacenie kar niż zbudowanie niewątpliwie kosztownej oczyszczalni ścieków". Opracowanie nowego prawa wodnego jest nakazem chwili. Istniejąca od roku komisja do opracowania nowej ustawy wodnej dopiero za dwa lub trzy lata ma zakończyć pracę. Może wcześniej udałoby się wydać realną ustawę o ochronie wód, stanowiąca część prawa wodnego. „Nie uratują nas kary ani nowe prawo wodne”. Trzeba nowych inwestycji, budowy nowych oczyszczalni ścieków miejskich i wód przemysłowych. Dotychczas pisano o korzyściach wynikających z odzyskiwania wartościowych składników ścieków, uciekajacych do morza. „Tymczasem rzeki tracą cierpliwość i naturalne dotąd zalety samooczyszczania”.

Trudno odpowiedzieć na pytanie, na ile owa niekiedy bardzo krytyczna publicystyka wpływała na potoczne postrzeganie problemów degradacji środowiska naturalnego. To, co można ustalić, to pojawienie się świadectw, które wskazują na rodzenie się społecznej świadomości zagrożeń z tego wynikających. Sa to listy do władz pisane przez obywateli PRL. Woda, jej brak i zanieczyszczenia stają się stałym tematem skarg kierowanych do centralnych instytucji państwa, w tym m.in. do Polskiego Radia. Oto np. w lipcu 1957 r. mieszkaniec wsi Łuszczewka Nowa w powiecie Pruszków skarżył się na przepływajacą niedaleko Utratę, która niesamowicie „zatruwa życie wszystkim gospodarzom, którzy w pobliżu mieszkają i nie mogą oddychać świeżym powietrzem [...]. Nie tylko, że człowiek pracuje na polu i oddycha tym smrodem w dzień, ale gdy przyjdzie się na wieczór do domu to trzeba czym prędzej zamykać okna i drzwi bo rzeczywiście jest jak w oborze gdy zacznie parować z tej rzeki”. Zanieczyszczenia powodowały straty w gospodarstwie „pod względem drobiu i bydła, które idzie do rzeki napić się wody i pada po jakimś czasie jak mucha”. Przyczyną zatrucia rzeki były ścieki z Mazowieckich Zakładów Przemysłu Drożdżowego 
w Józefowie ${ }^{41}$. W listach pisanych do radia słuchacze informowali i komentowali również inne zatrucia wód ściekami (np. Brdy w Bydgoszczy przez zakłady „Persil”42, wód we wspomnianym wcześniej Kręsku ${ }^{43}$ ).

W biuletynie listów do Polskiego Radia z 3 lipca 1959 r. zgromadzono skargi na wzmiankowane już zatrucie Odry przez NZPO „Rokita” w Brzegu Dolnym. W anonimie nadesłanym z pływającego po Odrze holownika „Mieczysław”, datowanym na 14 czerwca 1959 r., pisano: „Tony ryb zostały pozbawione życia przez Zakłady «Rokita» w Brzegu Dolnym. Patrząc na różnorodne cielska płynących ryb każdemu robi się żal, że zostały zatrute w tak bezmyślny sposób”. Zakłady te „drwia sobie z nas" na przetrzeni wielu lat, ,nie pomagają artykuły w gazetach ani radio”, woda z tych zakładów łączy się z wodą Odry i „to co w niej żyje ginie straszną śmiercia, zatruwając dodatkowo powietrze. Jestem naocznym śwadkiem, jak ludzie znad Odry odganiaja krowy i owce, aby nie zaszkodziła im woda z zakażonej rzeki" ${ }^{4}$. Podobnie komentował to masowe zatrucie ryb mieszkaniec Poznania: „Ze swej strony uważam, że jest to wandalizm ostatniego gatunku. Czy nie ma siły, ażeby temu łotrostwu położyć ostatecznie kres? Uważam, że karami pieniężnymi, jakie nakłada się na poszczególne fabryki nie zmieni [się] sytacji na lepsze, gdyż fabryki z góry planują pewne kwoty w swym budżecie rocznym na zapłacenie kary za wytrucie ryb, gdyż to bardziej im się opłaca, aniżeli instalowanie na terenie fabryki kosztownych urzadzeń filtracyjnych. Moim zdaniem czyny te winny być traktowane na równi z przestępstwami natury gospodarczej i [należy] stosować wobec winnych surowe kary"45.

Ten ostatni list jest bardzo wymownym świadectwem wzrastajacej świadomości zagrożeń wód przez toksyczne ścieki. Podobnie może być interpretowana skarga z 29 stycznia 1959 r., jaka napłynęła ze Szczecina i nawiązywała do wcześniej już wspomnianego zatrucia Odry fenolem. Jej autorka pisała: „Jestem mieszkanką Szczecina od wielu lat. Mieszkam w Śródmieściu. Szczecinianie pija wstrętną wodę z fenolem. Prasa wiele alarmowała w ubiegłym roku na ten temat. Długi

${ }^{41}$ TVP Ośrodek Dokumentacji i Zbiorów Programowych (dalej: ODiZP), Komitet do Spraw Radiofonii „Polskie Radio”(dalej KdSR), sygn. 1050/24, t. 1, Biuro Listów, Biuletyn nr 37 z 17 V 1958 dotyczacy zanieczyszczenia powietrza i rzek przez zakłady przemysłowe oraz bezpieczeństwa i higieny pracy w zakładach, k. 182.

${ }^{42}$ ODiZP, KdSR, sygn. 1475/2, Biuro Listów, Biuletyn nr 36, Warszawa, 3 VII 1959, bp.

43 Tamże.

44 Tamże.

45 Tamże. 
czas woziliśmy wodę z pomp, przed którymi oczywiście ustawiały się kilometrowe ogonki. Po pewnym czasie w prasie napisano, że woda nadaje się do picia, tzw. wodociagowa. W dalszym ciagu pijemy jednak tak bardzo szkodliwa dla organizmu wodę. [...] Dzieci mają być w przyszłości kalekami. Przecież dobrze jest nam wiadome, jak bardzo jest szkodliwy fenol. Atakuje wzrok, wątrobę, nerki i wiele innych narządów w naszym organizmie. Wiele konferencji już się odbyło na ten temat, ale jak dotąd nic się nie zmieniło. Jesteśmy po prostu skazani na powolne zatrucie" 46 .

Trudno jest na podstawie tych pojedynczych skarg formułować uprawnione wnioski na temat tego, jaki był zasięg społeczny takiego postrzegania problemów degradacji środowiska. Widomo jednak, że listy w tych sprawach stanowiły już w pierwszej połowie lat 60. istotny i stale powtarzający się wątek tematyczny korespondencji obywateli z władzami PRL ${ }^{47}$. Mogłoby to świadczyć o tym, że społeczne poczucie wagi tych spraw narodziło się wcześniej, w okresie destalinizacji, objętej analizą w tym artykule.

\section{Konkluzje}

Polski dyskurs na temat zanieczyszczeń wody przeszedł w analizowanym okresie znamienną ewolucję. W miarę postępów stalinizacji był on coraz bardziej watły, ograniczony do waskiego grona najwyższych władz partii i państwa oraz specjalistów. Prymat polityki forsownej industrializacji powodował, że kwestie jej skutków dla środowiska naturalnego były niedoceniane i minimalizowane. Skala degradacji środowiska, w tym zanieczyszczeń wody, była słabo rozpoznana. Pisano na ten temat niemal wyłącznie w niejawnych dokumentach urzędowych oraz w prasie specjalistycznej. To, że polskie rzeki powoli stawały się ściekami, miało wynikać z zaniedbań będących efektem „rabunkowej gospodarki kapitalistycznej”.

Destalinizacja spowodowała, że społeczny dyskurs o czystości polskich rzek poszerzył się i to nie tylko tematycznie (kwestie prawne,

${ }_{46}$ Tamże, 1050/28, Biuro Listów, Biuletyn nr 12, 6 marca 1959, bp.

47 Jak stwierdzono w biuletynie wewnętrznym Biura Listów Komitetu do Spraw Radia i Telewizji „Polskie Radio i Telewizja” z sierpnia 1966 r. na przestrzeni „ostatnich kilku lat liczba listów w sprawach zanieczyszczenia powietrza i wód wahała się w granicach 100-120 rocznie", a w ciagu I półrocza 1966 - wyniosła 46. Zob. ODiZP, Komitetu do Spraw Radia i Telewizji „Polskie Radio i Telewizja”, sygn. 1050/73, Biuletyn wewnętrzny nr 276, Warszawa, sierpień 1966, bp. 
organizacyjne, badań naukowych, koncepcji i technik oczyszczania ścieków). Zaczęła pisać na ten temat prasa codzienna, w której nie brakowało głosów krytycznych. Wydaje się, że świadomość zagrożeń wynikających z zatrucia wód powoli przenikała do opinii publicznej.

\section{Bibliografia}

Aleksandrowicz J., Wptyw zmian środowiska na zdrowie człowieka, Wrocław 1975.

Bontemps S., W sprawie zanieczyszczeń wód, „Gospodarka Rybna” 1955, nr 2. Borowy T., Nasze kłopoty z woda i ściekami, „Życie Warszawy” 1956, nr 82.

Brzeziński W., Ochrona prawna biologicznego środowiska człowieka, Warszawa 1971.

Cabejszek I., Koziorowski B., Malanowski Z., Charakterystyka higieniczno-sanitarna rzeki Wisty na odcinku Góra Kalwaria-Warszawa, „Gaz, Woda i Technika Sanitarna” 1956, nr 5, s. 175-181.

Cabejszek I., Malanowski Z., Włodek S., Zanieczyszczenie rzeki Bzury, „Gaz, Woda i Technika Sanitarna" 1952, nr 6, s. 162-167.

Chrzanowski F., Zanieczyszczenie wód śródladowych województwa gdańskiego, „Gospodarka Rybna” 1956, nr 7, s. 7-8.

Cyranowicz Z., Złoto mętnych wód, „Trybuna Ludu” 1960, nr 219.

Ekonomiczne aspekty ochrony środowiska, pod red. Adama Ginsberga-Geberta, Warszawa 1976,

Ekonomiczne i socjologiczne problemy ochrony środowiska, praca zbiorowa pod red. A. Ginsberta-Geberta, Wrocław-Warszawa-Kraków 1985.

Ekonomiczne i socjologiczne problemy ochrony środowiska, red. A. Ginsbert-Gebert, t. 2, Wrocław-Warszawa-Kraków 1988.

Jakubowski J., Motoryzacja i ochrona środowiska, Warszawa 1976.

Jaruzelski J., Otrute rzeki, „Życie Warszawy” 1958, nr 52, s. 3-4.

Joszt A., Ochrona rzek, „Gaz, Woda i Technika Sanitarna” 1952, nr 1, s. 21-24.

Juda J., Ochrona powietrza atmosferycznego, Warszawa 1974.

Goliszewski J., Stan zanieczyszczenia wód powierzchniowych w Polsce, „Gospodarka Wodna" 1961, nr 10, s. 430-435.

Keller T., Problem zdrowej wody, „Tygodnik Demokratyczny” 1955, nr 49, s. 7. Krysiński J., Węzłowe problemy ochrony czystości wód (organizacyjne, techniczno-ekonomiczne i prawne), „Gospodarka Wodna” 1961, nr 10, s. 416-420.

Lenar L., Park narodowy czy ścieki, „Życie Warszawy” 1956, nr 66, s. 8.

Łustacz L., Podstawowe zagadnienia prawne i organizacyjne ochrony środowiska, Warszawa 1976.

Mroziński W., Odra i jej doptywy na odcinku górnoślaskim, „Gaz, Woda i Technika Sanitarna" 1949, nr 11, s. 361-363.

Rudziński B., Zagadnienie dobrej wód, jako warunek dobrego zdrowia, „Gaz, Woda i Technika Sanitarna” 1946, nr 1, s. 20-21. 
Skoraszewski W., Rzeki czy ścieki?, „Gaz, Woda i Technika Sanitarna” 1956, nr 11, s. 405-406.

Surowiec S., Uwagi do ustawy o ochronie wód przed zanieczyszczeniem, „Gospodarka Wodna" 1961, nr 10, s. 426-427.

Symonowicz A., Bilans strat powstatych wskutek degradacji środowiska, Warszawa 1990.

System ochrony środowiska w Polsce, Wrocław 1978.

Szczerbińska M., Woda dla Warszawy, „Tygodnik Demokratyczny” 1955, nr 40 , s. 7.

Tatko T., Obecna sytuacja oczyszczalni ścieków w Polsce, „Gaz, Woda i Technika Sanitarna" 1958, nr 9, s. 342-344.

Trendota J., $W$ sprawie właściwych metod ochrony wód przed zanieczyszczeniem ściekami, „Gaz, Woda i Technika Sanitarna” 1956, nr 4, s. 142-143.

Wierzbicki J., Zanieczyszczenie rzek miejskimi i przemystowymi wodami ściekowymi, „Gazeta Obserwatora PIHM”, t. 2, 1949, nr 10, s. 1-3.

Zaczyński E., Zanieczyszczenie rzek Górnoślaskiego Okręgu Przemystowego, „Chrońmy Przyrodę Ojczystą" 1959, nr 4, s. 15-21.

Zajdel E., Ochrona czystości wód ważnym czynnikiem w gospodarce narodo$w e j$, „Życie Gospodarcze” 1954, nr 8, s. 305-306.

Dariusz Jarosz

The issue of water pollution in Poland in the years 1945-1961: introduction to research (Summary)

The research shows that as Stalinisation in Poland advanced, the discourse on water pollution was becoming more and more limited to a small group of the highest party and state officials and specialists. The implementation of the expansive industrialisation programme became a priority of the economic policy, which at the same time led to the issues of environmental pollution being sidelined. Due to lack of systematic studies on the issue in question, it is difficult to assess the scale and dynamic of the degradation of the natural environment. The problem was written about solely in classified administration documents and specialised press. According to the official political narrative, the problem of Polish rivers slowly becoming sewers was the aftermath of negligence resulting from the "exploitative capitalist economy" of the times of the partitions and the interwar period.

De-Stalinisaton led to the social discourse on the quality of Polish rivers becoming much wider, not only thematically (legal and organisational issues, academic research, approaches to sewage treatment and its techniques). The issue started to be addressed, often critically, by daily newspapers. It seems that the general public was becoming aware of dangers brought about by water contamination. This emerging conscience is reflected by the tone and content of letters on the subject sent to the Polish Radio. 
Dariusz Jarosz - prof. dr hab., pracownik Instytutu Historii im. Tadeusza Manteuffla PAN; specjalista w zakresie historii społecznej Polski w latach 1944-1989 i stosunków PRL z Francja. Autor m.in.: z Marią Pasztor, Stosunki polsko-francuskie 1944-1980 (Warszawa 2008); z M. Pasztor, Afera mięsna: fakty i konteksty (Torun 2004); Polacy a stalinizm 1948-1956 (Warszawa 2000); „Masy pracujace przede wszystkim”. Organizacja wypoczynku w Polsce 1945-1956 (Warszawa-Kielce 2003); Mieszkanie się należy... Studium $z$ peerelowskich praktyk spotecznych (Warszawa 2010); z G. Miernikiem, „Zhańbiona” wieś Okót: opowieści o buncie (Warszawa-Kielce 2016). E-mail: darjarosz@wp.pl. 